\title{
TEMPO E ESPAÇO NA AUTOFICÇÃO A CONFISSÃO DE LÚCIO, DE MÁRIO DE SÁ-CARNEIRO
}

Lucy Ferreira Azevedo*

https://orcid.org/0000-0002-7072-3859

Sidney Barbosa**

https://orcid.org/Ouol.com.br000-0003-4311-9629

Como citar este artigo: AZEVEDO, L. F.; BARBOSA, S. Tempo e espaço na autoficção A confissão de Lúcio, de Mário de Sá-Carneiro. Todas as Letras - Revista de Lingua e Literatura, São Paulo, v. 22, n. 3, p. 1-17, set./dez. 2020. DOI 10.5935/19806914/eLETDO2013630

Submissão: julho de 2020. Aceite: setembro de 2020.

Resumo: A autoficção A confissão de Lúcio, de Mário de Sá-Carneiro, é uma narrativa em que o personagem Lúcio, um escritor português, confessa, após dez anos na prisão, que não cometera o crime pelo qual estava pagando. Diante do questionamento sobre qual seria o comprometimento das artes na representação do tempo e espaço na autoficção de Mário de Sá-Carneiro, objetiva-se com este artigo associar o cronotopo bakhtiniano com a metáfora da bruma, forma simbólica que criamos para analisar como o escritor modernista e sensacionista construiu sensações, reflexões das personagens e ações a partir das imagens proporcionadas pelas artes parisienses, conjugando tempo e espaço com devaneios imagéticos. A reflexão metodológica restringir-se-á à análise dos momentos/diálogos em que os artistas falam de si, das sensações e das artes.

Palavras-chave: Autoficção. Cronotopo. Literatura e outras artes. Metáforas imagéticas. Tempo e espaço. 
O espaço já não é senão o tempo que traz verdadeiramente as forças de solidariedade do ser. $O$ alhures não age mais sobre o aqui do que o outrora age sobre o agora (Gaston Bachelard)

\section{INTRODUÇÃO}

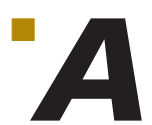

confissão de Lúcio (1914), de Mário de Sá-Carneiro, é uma obra que representou uma ruptura com a tradição portuguesa em relação à sua liberdade criadora e ao rompimento com o passado - ora o nacionalismo português, ora a força da vanguarda europeia, uma quimera no sentido grego. Sá-Carneiro foi um dos criadores da revista Orpheu, influenciado pelas vanguardas artísticas da época e pelo movimento criado por ele mesmo, juntamente com seu amigo Fernando Pessoa - o sensacionismo. Por isso ele é tido como um modernista (romântico-sensacionista) da primeira geração.

Tanto sua obra poética quanto a em prosa constituem um patrimônio para os seus contemporâneos e para as gerações que o sucederam.

Sua narração pode ser considerada um tipo de autoficção ${ }^{1}$, uma vez que mostra espírito crítico e questionador sobre a própria criação literária. Constituem características desse gênero literário a temática mais particular/individual, a comunicação direta das ideias, a exposição da vida interior sempre em clima de memorial. O autor (e também o narrador da obra) é fiel ao seguir a corrente literária criada por ele e Fernando Pessoa. Esta pretendia ser a síntese entre todas as artes, uma espécie de literatura híbrida com recursos estilísticos bem complexos, modernos e de realização estética inovadora. Expressava suas sensações o mais importante para uma poética que pretendia, além de ser síntese das artes do começo do século XX (música, teatro, arquitetura, dança, entre outras), dar ênfase às cores que evocam muitas emoções. O escopo era conseguir expressar a sensação como: "[...] dependente da materialidade do espaço ou do texto, mas liberta nas asas do tempo e do sonho. Enfim, a sensação absoluta" (COSTA, 1990). Trata-se de uma sensação espaço-temporal muito evocada no romance que estudamos e que provoca a relação intrínseca à referencialidade, comunhão da narrativa e do ambiente externo, a saber, o tempo das vivências do personagem Lúcio e seu grupo de amigos e amores em Paris, na época das vanguardas do início do século XX.

O grupo de artistas, incluindo dramaturgos, escritores, arquitetos, não traduzia a vida humana pelo viver cotidiano comum, mas pelas sensações evocadas pela arte que, enfaticamente, tinham Paris como principal ambiente e o seu tempo presente. Ele, por outro lado, projetava outro tempo presente utópico, ou seja, o ideal estético apenas mensurável pela arte.

A obra transita entre o verossímil e o inverossimil, complexamente arquitetada a partir das sensações evocadas pela arte e pelo olhar do artista diante de diferentes manifestações artísticas. Segundo Ricardo, parte do triângulo amoroso imaginado por Mário de Sá-Carneiro (1973, p. 64) em sua autoficção, os artistas sentem a vida pela sensação: "somos todos álcool, todos álcool! - álcool que nos esvai em lume".

\footnotetext{
O termo "autoficção" foi criado pelo escritor francês Serge Doubrovsky na esteira do termo "autobiografia", disseminado pelo crítico Philippe Lejeune. Nas palavras de Doubrovsky, "autoficção é a ficção de fatos e acontecimentos estritamente reais", ou ainda "autobiografia ou autoficção, a narrativa de si é sempre modelagem, roteirização romanesca da própria vida" (FAEDRICH, 2016, p. 30-46).
} 
Com Serge Doubrovsky, em $1977^{2}$, a crítica literária passou a denominar autoficção a possibilidade de fazer-se a leitura referencial (conteudística) e ficcional de um mesmo texto com referência ao seu próprio romance Fils.

Desse modo, aquilo que Mário de Sá-Carneiro chamara autobiografia, em nova leitura, recebe outra classificação da crítica literária. Vida e arte, verossímil e inverossímil, história e imaginação são oposições que envolvem subjetividades que o olhar do artista propõe a seu leitor e o faz conjecturar sobre qual seria o comprometimento das artes na representação do tempo e do espaço da autoficção de Mário de Sá-Carneiro.

O recorte dado ao tema, neste artigo, concentra-se no ponto de partida teórico que é o cronotopo bakhtiniano (BAKHTIN, 2010), desenvolvido em seus estudos sobre um dos principais componentes do tempo na autoficção e em toda a narrativa, no qual vincula e adensa tempo e espaço numa só manifestação, de forma imbricada. Assim, em um breve levantamento das obras de arte que possam ter influenciado seu recorte, destacam-se: o impressionismo na pintura, com a produção de Monet e de Renoir, por exemplo; o antigo gótico da arquitetura medieval e na literatura; o romântico; o surrealista no futuro próximo; e o sensacionismo português, tão caro a Alberto Caeiro.

Para concretizar o amálgama tempo-espaço, construiu-se, então, a metáfora da bruma como portal entre os paradigmas que talvez tenham sugestionado, in medias res, o olhar do artista: vida e arte, verossímil e inverossimil, história e imaginação. Os diálogos vivenciados por Lúcio e os amigos são criados a partir das artes exibidas e que circulam em Paris, tomadas pelo narrador como parte de uma grande galeria de tesouros artísticos.

Lúcio, o personagem principal, é um escritor que redige uma confissão sobre um crime que havia cometido; todavia, ele alega não ter matado a amante. Lembra-se dele após dez anos na prisão, tempo que passou sem se defender. Não o fez porque a vida no tempo histórico não o interessava e o artista sucumbiu na bruma Vida e Arte que o envolvia e o submetia durante toda a sua vida fora do cárcere. Isso acontecia a ponto de ele garantir que a sua confissão não teria importância, para não se tornar uma peça jurídica capaz de o defender, ao fazer o registro semântico de que ela seria um "mero documento".

Assim, completamente entregue a ver a vida pela ótica das artes, suas sensações dirigem suas leituras, que são também de vida e de arte, de tempo e de espaço.

Suas imagens artísticas - metáforas imagéticas - precisavam de uma base orgânica e Paris era o cenário ideal e concreto do tempo e do espaço. Trata-se do espaço urbano da expressão de todas as forças: sociais, politicas, econômicas, intelectuais e artísticas. É a famosa Belle Époque, marcada pelos comportamentos de "extroversão, abastança, sossego, fé no progresso, divertimento e uma parte de nostalgia de um tempo sonhado".

Em A confissão de Lúcio, a imaginação criadora e a composição das personagens fazem o tempo apresentar-se sempre presente, juntamente com a sua união indivisível com o espaço (cronotopo bakhtiniano). Como afirmamos anteriormente, nesta obra a arte é a bruma/metáfora que envolve tempo e espaço,

2 Na verdade, esse autor apresenta essa palavra na contracapa de um romance que publicou naquele momento. Trata-se de Fils, seu terceiro romance, publicado em 1977. Serge Doubrovsky lançou as bases da autoficção, um gênero entre a autobiografia e a ficção que floresceu nos estudos literários. 
consolidada por meio de imagens que emergem das sensações, compondo uma espécie de névoa que envolve a tudo, inclusive o tempo e o espaço, tornando indeléveis as experiências e vivências das personagens.

\section{LITERATURA E OUTRAS ARTES ENFUMAÇADAS NA METÁFORA DA BRUMA}

Conforme Coutinho (1978), se literatura é a criação de uma outra realidade, independentemente da veracidade do autor e das experiências colhidas por ele, logo, torna-se coerente a afirmação de Ricardo (principal interlocutor de Lúcio) acerca de a linha divisória entre o verossímil e o inverossímil ter o nome de Arte.

No início da trama de A confissão de Lúcio, ele (Ricardo) discorre que existe um portal imaginário no qual o artista transita e o real passa a ser direcionado por essa realidade distinta que só ele é capaz de apreender e vivenciar. E, para tanto, o autor recorreu a cenas de Paris, no tempo da moenda, palavra que remete a mó (ligada ao destino) e a moinho (ligada a vento, dispersão e ilusão): “a orquestra moía valsas" (p. 36), isto é, aquela vida desvairada e desencontrada que as personagens viviam em Paris tinha a marca do devaneio e a força da fatalidade, do destino. É como se uma bruma cinzenta e dispersa cobrisse todo aquele cenário de aparente felicidade e alegria.

\section{TEMPO E ESPAÇO EM FUSÃo}

Bakhtin (2014, p. 211) explica que a inspiração para a criação do conceito de cronotopo lhe ocorreu a partir de Einstein: "Não é importante para nós esse sentido específico que ele tem na Teoria da Relatividade [...] nele é importante a expressão da indissolubilidade de espaço e de tempo". Porém, aspectos de sua teoria sobre tempo e espaço encontram, igualmente, respaldo nos trabalhos do filósofo Kant (1724-1804) e nos do arquiteto e pintor Ukhtomski³. Em seus escritos, ele já realçava a importância de o estudioso de arte considerar a ligação intrínseca que existe entre tempo e espaço.

Amorim (2012) explica que o teórico russo estudou tempo e espaço em dois prismas: no texto literário e em outras atividades criadoras. Foram criados os termos cronotopo e exotopia em diferentes momentos de suas reflexões. Foi no ensaio "Formas de tempo e de cronotopo no romance: ensaios de poética histórica” (1937-1938) que ele fundamentou o conceito de cronotopo: “À interligação fundamental das relações temporais e espaciais, artisticamente assimiladas em literatura, chamaremos de cronotopo" (BAKHTIN, 2014, p. 211).

No nosso trabalho, pensamos que há ajustamento entre o conceito de indissolubilidade espaço-temporal e as situações criadas por Sá-Carneiro, pois a autoficção é um campo profícuo para a análise do tempo e do espaço como amálgama na trama. Conforme Machado (2012, p. 159), "os gêneros se constituem a partir de situações cronotrópicas particulares e também recorrentes, por isso são tão antigos quanto as organizações sociais".

3 Konstantin Andreyevich Ukhtomsky (1818-1879), arquiteto e pintor que ficou famoso por suas aquarelas, notadamente pelas que fez dos interiores do Museu Hermitage, em São Petersburgo. 
O reconhecimento que Ricardo faz da realidade distinta que experimenta quando transita pelo portal imaginário encontra afinidade com o que Bakhtin (1997, p. 43) reflete: "quando contemplo um homem situado fora de mim e à minha frente, nossos horizontes concretos, tais como são efetivamente vividos por nós dois, não coincidem".

Assim, as sensações, a arte, o tempo, o espaço e a vida cotidiana passam por distorções aos olhos das personagens que observam e provocam aceitação ou não dos valores para ser um dado de criação, não pelos valores dos olhos contemplativos, mas pela visão do outro em si mesmo. Dessa forma, Bakhtin entende a leitura e postula seu entendimento de exotopia (um excedente de visão), ou seja, o olhar do outro no confronto proporcionado pelo diálogo, cada um em seu contexto próprio. Esse embate é o que alimenta o excedente de visão, algo que empaticamente o eu assimila fora de si mesmo.

O personagem vivencia sensações provocadas pela arquitetura de Paris para materializar seu temor da vida no tempo e no espaço, presentificados nos arcos e em outras formas arquitetônicas da Cidade Luz. Mesmo com referência ao passado histórico representado pelos monumentos parisienses, os personagens-artistas presentificam a sensação de duração daquele espaço urbano como se fosse um presente eterno.

Mas não são estes só os meus medos. Tenho muitos outros. Por exemplo, o horror dos arcos - de alguns arcos triunfais $e$, sobretudo, de alguns velhos arcos de ruas. Não propriamente dos arcos - antes, do espaço aéreo que eles enquadram. E lembro-me de haver experimentado uma sensação misteriosa de pavor, ao descobrir no fim de uma rua solitária de não sei que capital um pequeno arco ou, melhor, uma porta aberta sobre o infinito (SÁ-CARNEIRO, 1973, p. 54).

Porém, neste contexto de um tratamento diferenciado da temporalidade, algum personagem excedia sua atuação, como é o caso de Marta, que, para além ou justamente por causa da sua situação misteriosa, vivia envolta em névoa densa com maior obscuridade do que os demais personagens, já por si nebulosos. Ela se apresentava como alguém que não tivesse relação com o tempo, pois levava uma vida de dissolução na busca constante do prazer e da sensualidade, tornando-se, assim, atemporal, vivendo apenas para o minuto presente:

E foi então que me ocorreu outra circunstância ainda mais estranha, a qual me acabou de perturbar: essa mulher não tinha recordações; essa mulher nunca se referia a uma saudade em sua vida. Sim. Nunca me falara de um sitio [...] da mais pequena coisa: um laço, uma flor, um véu... [...] De maneira que a realidade inquietante era esta: aquela mulher erguia-se aos meus olhos como se não tivesse passado - como se tivesse apenas um presente! (p. 84).

No entanto, Ricardo continua expondo sua relação de medo na representação da arquitetura, como se vê quando afirma que "quando era pequeno - ora, ainda hoje! - apavoravam-me as ogivas das catedrais, as abóbadas, as sombras de altas colunas, os obeliscos, as grandes escadarias de mármore...” (p. 54). 
Figura 1 - O colorido e a exaltação da luz na rosácea da Sainte-Chapelle, em Paris

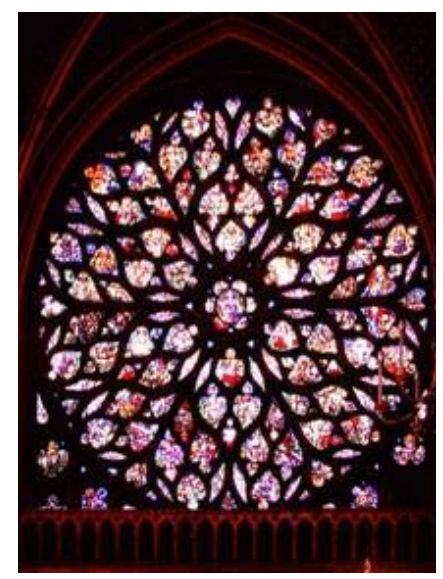

Nas construções religiosas de estilo românico (séculos X, XI e XII), em meio a um interior pouco iluminado, às vezes irrompem algumas rosáceas como pontos de luz, símbolo de Deus, da espiritualidade e de tudo que é santo e bom. Essa tendência à entrada e captação da luz natural encontrará, no entanto, o seu auge com as construções das catedrais góticas. Ao contrário do estilo românico mais simples e que apresentava, em suas construções, arcos redondos (arco pleno ou da volta perfeita), paredes baixas e grossas, grandes colunas e janelas pequenas, o estilo gótico (séculos XIII, XIV e XV) era majestoso e opressor. Com sua grandiosidade e altura (afiançadas pelos contrafortes), vitrais coloridos e suas ogivas (arco quebrado ou ogival), procurava como expressão da fé dominar o homem, rebaixando-o à sua pequenez diante do Divino. Tratava-se da manifestação de poder da classe aristocrática, que tinha na Igreja a mão-posta para a instrumentação de toda a sociedade. Deus estava a serviço da alta sociedade, não do povo, dos simples e dos pobres, como pregava o Evangelho de Jesus. A arquitetura cristã, embora esteticamente rica e criativa, registrava em si todas essas contradições.

Tempos de uma fé imposta, impregnada de pavor sob a forma dessa arquitetura esmagadora das pessoas, ainda tomava o artista, séculos depois. O que não surpreende, uma vez que os artistas sempre se deixaram possuir pelas sensações provocadas pelo externo a eles e pelos apelos à baixeza do homem diante da grandiosidade de Deus.

Senão vejamos: 
Figura 2 - Basílica Saint-Denis, nos arredores de Paris, onde eram enterrados os reis de França. Impossivel não se sentir pequeno diante de Deus ao adentrar esse recinto e sua arquitetura ${ }^{4}$

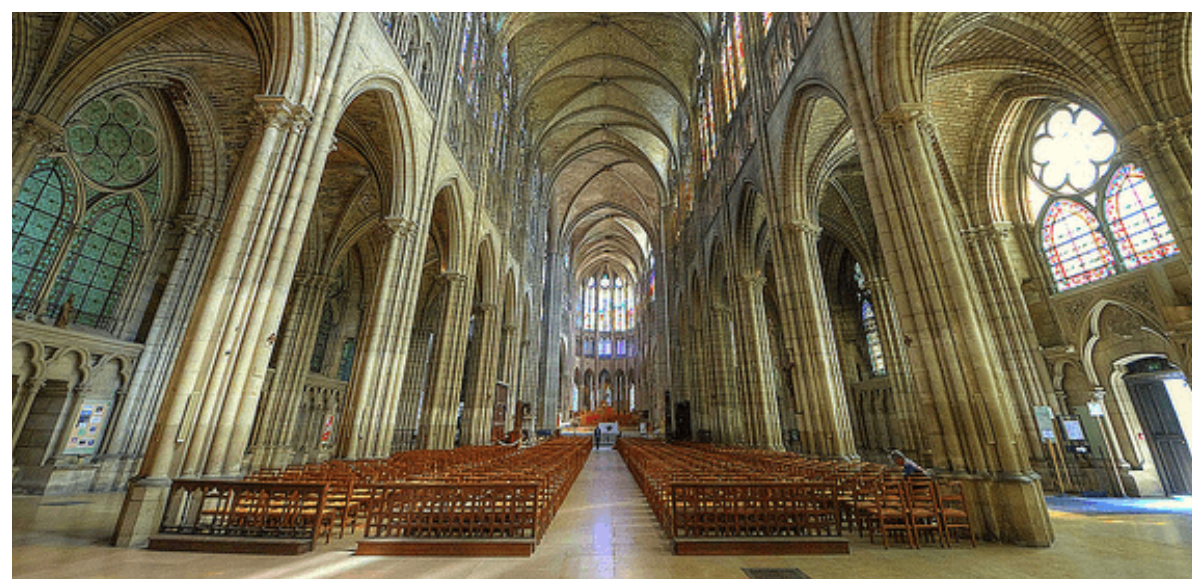

A imagem suntuosa, externa, está aqui vivenciada de modo volitivo-emocional e corresponde à cronologia do tempo presente, pela força do verbal que atualiza por intermédio da expressão "ora", denotativa da importância de quem vive o agora. Ricardo assinala: "quando eu era pequeno..." / "ora, ainda hoje!" - a fim de mostrar toda a formação de uma imagem externa criada não só para expressar outra forma como também para impressionar do ponto de vista artístico. Trata-se de um tempo histórico lançado arquitetonicamente no espaço.

As sensações têm como berço a arte. É ela que envolve em bruma as sensações, criando um véu para cobrir o mundo real e transportando o tempo da sensação para um espasmo momentâneo ou de uma fuga transitória da realidade. Sensações que traduziam emoções subjetivas, lembranças pessoais, fantasias e desejos. Nesse enfoque, no entanto, o desejo aponta para o devir, a vontade de realizar o objeto estético, porém repudiado no presente.

Ricardo e Marta felicitaram-me muito pela minha obra - creio. Mas não o posso afirmar, em virtude do denso véu de bruma cinzenta que me envolvera, e que só me deixou nítidas as lembranças que já referi (SÁ-CARNEIRO, 1973, p. 132-133, grifo nosso).

Em outras circunstâncias (dramáticas), não é a bruma que se manifesta para apagar fatos, cobrir situações afetivas, esquecer uma época ou fazer desaparecer lugares. Ali é o silêncio ou a simples volatização, como se pode observar naquele instante culminante da tragédia ocorrida, no evento em que o narrador volta a si e descobre não o corpo de Marta (que havia tombado sob os tiros do revólver) e, sim, constata, de modo claro e explícito, que os restos mortais ali caídos eram de seu amigo Ricardo. Esse paradoxo enseja não mais a opacidade brumosa da metáfora predominante no texto, mas a visão clara e objetiva de sua realidade: a morta não era Marta, mas Ricardo, o seu objeto de desejo:

4 Disponível em: https://omelhordeparis.com.br/4-lugares-incomuns-em-paris. Acesso em: 7 out. 2020 
Ó assombro! Ó quebranto! Quem jazia estiraçado junto da janela não era Marta - não! -, era Ricardo... E aos meus pés - sim - aos meus pés! - caíra o seu revólver ainda fumegante!

Marta, essa desaparecera, evolara-se em silêncio, como se extingue uma chama... (p. 157).

O romance apresenta imagens representativas de um velho mundo que, para aquele grupo de artistas, apresentava-se como suprarrealidade, porque a arte impunha impressões só sentidas por aqueles que conviviam com ela. Os espaços colossais, os grandes vãos de igrejas impressionavam, mas para o grupo de artistas no romance eram muito mais do que isso, porque eles (artistas) acreditavam-se destinados para além do humano, seres intocáveis e especiais quando imersos em arte. "Cá estamos: a maldita literatura"; "vocês, os verdadeiros artistas, as verdadeiras grandes almas - eu sei - nunca saem, nem pretendem sair, do vosso círculo de ouro" (p. 49).

São partes de diálogos, no capítulo 2 , em que Ricardo reflete sobre o fato de a arte enclausurar o artista e mantê-lo inseparável em seu tempo presente ("Cá estamos:") em amálgama com o lugar ("círculo de ouro"). O personagem Lúcio faz marcas espaciais na capital francesa, com o cotidiano de sua vida especial de artista: "por fim o nosso coupé estacou em face de um magnífico palácio da Avenida do Bosque, todo iluminado através de cortinas vermelhas, de seda, fantasticamente" (p. 49). O personagem assinala as sensações de tempo em lugares ritualísticos do meio artístico na Cidade Luz e também nos bares e cabarés.

Figura 3 - Um Bar no Folies-Bergère (1882), de Édouard Manet ${ }^{5}$

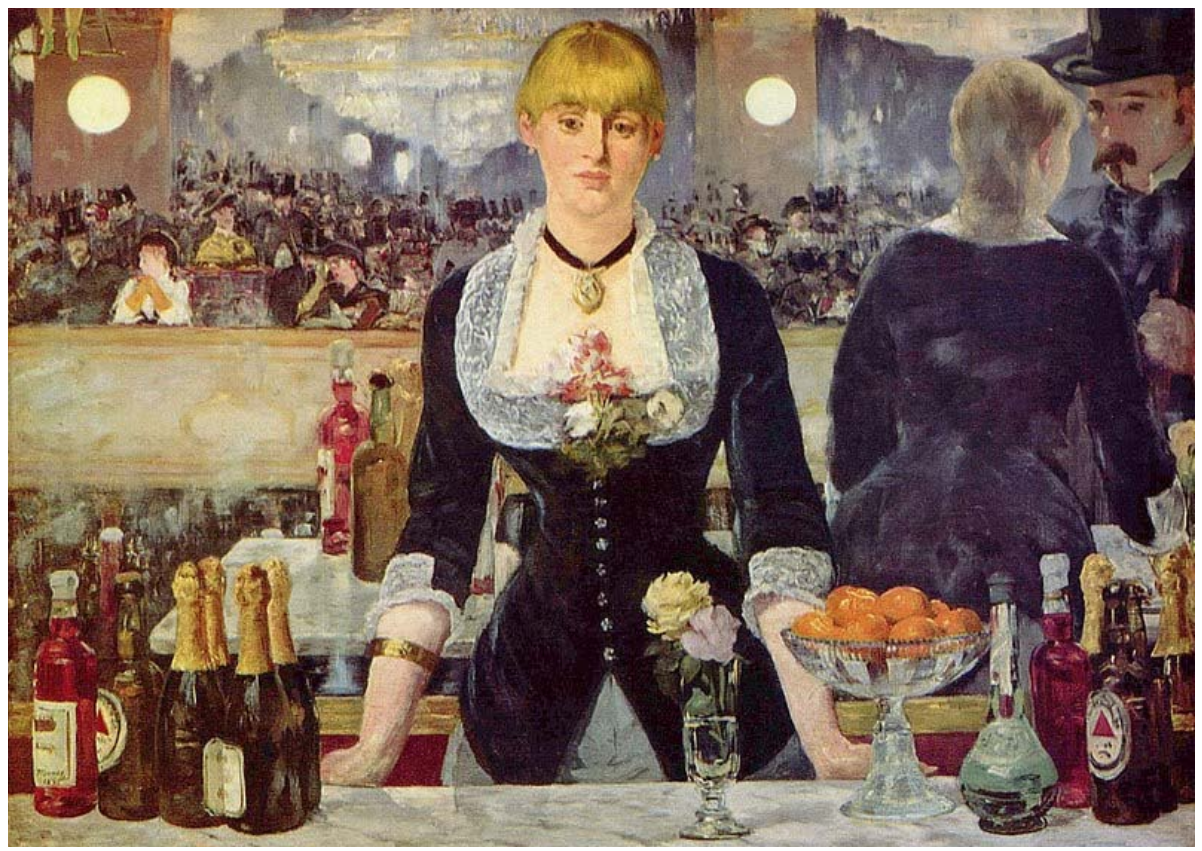

5 Disponível em: https://pt.wikipedia.org/wiki/Um_Bar_no_Folies-Berg\%C3\%A8re. Acesso em: 7 out. 2020. 
O quadro apresenta a expressão em que Édouard Manet capta um dos muitos pontos boêmios de Paris. Ali vemos onde grupos de conversa se amontoavam e formavam um mosaico de pessoas e também de ideias. Essas são denotadas pela representação, no quadro, de vários diálogos e pela neutralidade, uma quase indiferença, do personagem que serve e realiza o serviço.

As impressões da moça com o olhar vago sobre a multidão, uma multidão real ou espelhada, talvez em diálogo com um homem que está fora de perspectiva, proporcionam uma intersecção possivel entre o impressionismo do pintor e o texto do sensacionista Mário de Sá-Carneiro. Esses dois temas, o do sensacionismo e o do discurso pictórico, concretizam a bruma em seus traços - a metáfora da bruma, um portal entre o real e o imaginário, unindo o verossímil e o inverossímil, o verdadeiro e o apenas verossimilhante.

Uma grande sala elíptica, cujo teto era uma elevadissima cúpula rutilante, sustentada por colunas multicolores em mágicas volutas. Ao fundo, um estranho palco erguido sobre esfinges bronzeadas, do qual - por degraus de mármore rosa - se descia a uma larga piscina semicircular, cheia de água translúcida. Três ordens de galerias - de forma que todo o aspecto da grande sala era o de um opulento, fantástico teatro (p. 36).

Neste trecho, em que a americana anfitriã chama de "espetáculo" as instalações de sua casa, é praticamente impossivel fazer uma descrição pela beleza criada por Mário de Sá-Carneiro. Aí, Lúcio passa dadivoso da arquitetura para a música e desta para o teatro, com seus recursos cênicos de luz e de cenografia. Muitas vezes esses dispositivos estão impregnados de cores, principalmente com o dourado, naquele castelo construído pela americana no eixo do tempo, que passou a ser inverossímil a ponto de todos os convidados para a inauguração sentirem-se perdidos ao sair da instalação que ali foi representada:

O ar fresco da noite, vergastando-nos, fez-nos despertar, e como se chegássemos de um sonho que os três houvéssemos sonhado - olhamo-nos inquietos, num espanto mudo. Sim, a impressão fora tão forte, a maravilha tão alucinadora, que não tivemos ânimo para dizer uma palavra. Esmagados, aturdidos, cada um de nós voltou para sua casa... (p. 45).

Aquele espaço (o castelo da americana) sofrera uma reforma e parecia um recinto criado somente para aquela noite. Tanto é assim que não há descrição de outras partes do imóvel, mas apenas a da sala-teatro. Era madrugada e a artista propunha uma grande cena em um grande espaço. O intuito da hipérbole espacial e do centramento artístico nos aspectos da arquitetura teatral era impressionar os convivas sem deixar outra possibilidade de sensação que não fosse a admiração, o embevecimento.

Isso ocorre também em outros trechos da narrativa autoficcional em que o espaço toma a dianteira da cena, tornando-se um personagem, um "actante" fundamental. No texto, por exemplo, os trechos referentes à cidade de Paris como um todo e a sua arquitetura são idealizados e até mesmo endeusados, servindo à causa do engajamento daqueles personagens com ele e com o ambiente artístico. É o que podemos verificar a seguir:

Raros traços comuns entre os nossos caracteres. Mesmo a bem dizer, só numa coisa iguais: no nosso amor por Paris. 
- Paris! Paris! - exclamava o poeta. - Por que o amo tanto? Não sei... Basta lembrar-me que existo na capital latina, para uma onda de orgulho, de júbilo $e$ ascensão se encapelar dentro de mim. É o único ópio louro para a minha dorParis!

Como eu amo as suas ruas, as suas praças, as suas avenidas! Ao recordá-las longe delas em miragem nimbada, todas me surgem num resvalamento arqueado que me traspassa em luz. [...]

De Paris, amo tudo com igual amor: os seus monumentos, os seus teatros, os seus bulevares, os seus jardins, as suas árvores... Tudo nele me é heráldico, me é litúrgico (p. 58).

Além da exaltação do espaço denominado Paris, há também uma referência a esse mesmo sítio singular que é a cidade e que lhe é acrescentada como a metáfora da nebulosidade de que se trata aqui. Ela faz parte do imbricamento que redundará no cronotopo. Isso ocorre, uma vez que ele é, por outro lado, "ópio louro" e "miragem nimbada". O ópio remete à evasão, à alucinação (fuga pelo uso de drogas) e à ilusão que, segundo o Dicionário Aurélio, é uma "confusão que faz com que alguém não consiga distinguir a aparência da realidade". Ora, é justamente esta a questão desses personagens artistas que, no seu devaneio, constantemente confundem essas duas categorias e tomam uma pela outra. Já miragem denota, no mesmo dicionário, "o que é fruto da imaginação; aquilo que tende a ser ótimo, mas não é verdadeiro". Verificamos, então, o espaço sendo tratado nesta narrativa não apenas como um componente da ambientação ${ }^{6}$, espécie de pano de fundo para o desenvolvimento da ação, mas como um componente denominado topofilia ${ }^{7}$, elemento fundamental para o desenvolvimento da trama. Os personagens - artistas de várias modalidades - e o espaço físico - a cidade de Paris - só fazem envolverem-se profundamente com esse ambiente. A trama só se desenrolará, isto é, somente dará condições para a história realizar-se devido a essa forte ligação entre personagens e espaço. Porém, este é marcado, como vimos, pela imposição do tempo sobre o espaço. O cronotopo, segundo a visão de Bakhtin, impõe-se como pedra basilar dessa autoficção. Aqui, mais do que alhures, ocorre essa junção de tempo e espaço, companheiros inseparáveis na Filosofia, nas Ciências e na Literatura.

Nos anos 30 do século XX, o pensador russo Mikhail Bakhtin traz para a análise literária o conceito de cronotopo. Certamente, Bakhtin não foi o primeiro a se preocupar com essa relação indissociável do espaço-tempo na literatura e em outras artes. Por exemplo, antes dele, em 1921, Edwin Muir já destacava essa relação em seu livro A estrutura do romance. No entanto, Bakhtin foi o teórico que introduziu a palavra e o conceito de cronotopo nos estudos literários. Como ele próprio explica, esse termo foi retirado das ciências exatas e trazido para o campo dos estudos literários "quase como uma metáfora" (BORGES FILHO; BARBOSA, 2015, p. 319).

No livro que estamos estudando, o tempo, em qualquer fase do dia, no cotidiano comum daquele grupo de artistas, é sempre marcado e vai de par com o

\footnotetext{
6 Para Osman Lins (1976, p. 77), ambientação é "o conjunto de processos conhecidos ou possíveis, destinados a provocar, na narrativa, a noção de um determinado ambiente".

7 Segundo Yi-fu Tuan (1980, p. 5), topofilia "é o elo afetivo entre a pessoa e o lugar ou ambiente físico".
} 
lugar onde acontecerão os encontros. Assim, Paris aparece em seus bares, esquinas, teatros e no tempo cíclico e das sensações dos embates dos artistas: acordar tarde, ir para os bares, não perceber a noite que se esvai constituem um tempo histórico condicionado aos costumes próprios daqueles amigos naquela cidade - seu tempo natural nos lugares dos rituais sociais. As sensações, nessas situações, carregam o olhar central da imagem de quem a constrói, que acredita na veracidade do visível e na intuição dos sentidos, o segundo como essencial. Com essa imagem, o pintor mescla tempo e espaço, criando uma espécie de cronotopo pictórico.

Diante da indagação sobre o futuro que o leitor possa colocar, pensa-se que está na dimensão do devir. Aqui também é a "metáfora da bruma" a condutora do futuro, da imagem perfeita, o tempo/lugar a que o artista ambiciona ir e realizar-se. É, portanto, no presente que o artista encontra o futuro como nascedouro de diferentes criações artísticas. Algo que vai surgir a partir da imagem dispersa e volátil. É isso que podemos constatar no trecho a seguir:

[...] - mas, sobretudo, de ondas que projetores ocultos nas galerias golfavam em esplendor. Ora essas torrentes luminosas, todas orientadas para o mesmo ponto quimérico do espaço, convergiam nele num turbilhão - $e$, desse turbilhão meteórico, é que elas realmente, em ricochete enclavinhado, se projetavam sobre paredes e colunas, se espalhavam no ambiente da sala, apoteotizando-a. De forma que a luz total era uma projeção da própria luz - em outra luz, seguramente, mas a verdade é que a maravilha que nos iluminava - nos não parecia luz. Afigurava-se-nos qualquer outra coisa - um fluido novo (p. 39).

Além de haver cismado com a palavra "luz", que, como vimos no trecho referido, denota busca espiritual, do sagrado e da vida, Lúcio faz aqui leituras possiveis da força do tempo que carrega consigo o espaço (e não o contrário) e a realização de seus desejos no eixo do tempo.

$\mathrm{Na}$ Paris do início do século XX, um relógio é o que sinaliza, por meio das luzes e cores, as transformações temporais e de lugar em movimentos intensos da vida humana ou de suas sensações - momentos do dia em determinado local, com a acuidade da sensação apreendida. Tem-se o espaço modificado em função do tempo:

Todo o cenário mudara - era como se fosse outro o salão. Inundava-o um perfume denso, arrepiante de êxtases, silvava-o uma brisa misteriosa, uma brisa cinzenta com laivos amarelos - não sei por que, pareceu-me assim, bizarramente-, aragem que nos fustigava a carne em novos arrepios (p. 38).

Para aquele grupo de amigos, o teatro sempre exercia atração e frequentá-lo era questão de obrigação. Era tomado como lugar quase idílico. Como no exemplo do teatro de gênero musical, quando Ricardo considera a força de todo o envolvimento de um palco e sua capacidade de total transformação do ser humano a ponto de coletivizá-lo:

É que, não sei se reparou, em todos os music-halls tornaram-se agora moda estes bailados por ranchos de raparigas inglesas. Ora essas criaturinhas são todas iguais, sempre - vestidas dos mesmos fatos, com as mesmas pernas nuas, as mesmas feições ténues, o mesmo ar gentil. De maneira que eu em vão me esforço por considerar cada uma delas como uma individualidade (p. 53-54). 
DOSSIÊ

\section{O CORPO COMO MARCA DE TEMPO E ESPAÇO}

Entre outros marcadores de temporalidade e da espacialidade, aparece o corpo que, diferentemente do que aponta Pierre Bourdieu (2015), é socializado. Deve carregar em si uma capacidade gerativa e criativa das formas como o homem interage na sociedade e na autoficção. Ele é o lócus máximo de expressão de sensações de espaço e de tempo, uma vez que é no corpo que expressamos melhor nossas emoções e é nele que o tempo deixa suas marcas, seja no desenvolvimento, seja no envelhecimento. É apreendido pelo leitor como imerso no cenário e a aparência tem valor informativo e não apresenta o peso social fundamental. No desenrolar dos fatos narrados, o corpo recebe, por parte do narrador, uma valorização algo mais física que espiritual.

\section{Figura 4 - O Suicídio (1877), de Pierre-Auguste Renoir ${ }^{8}$}

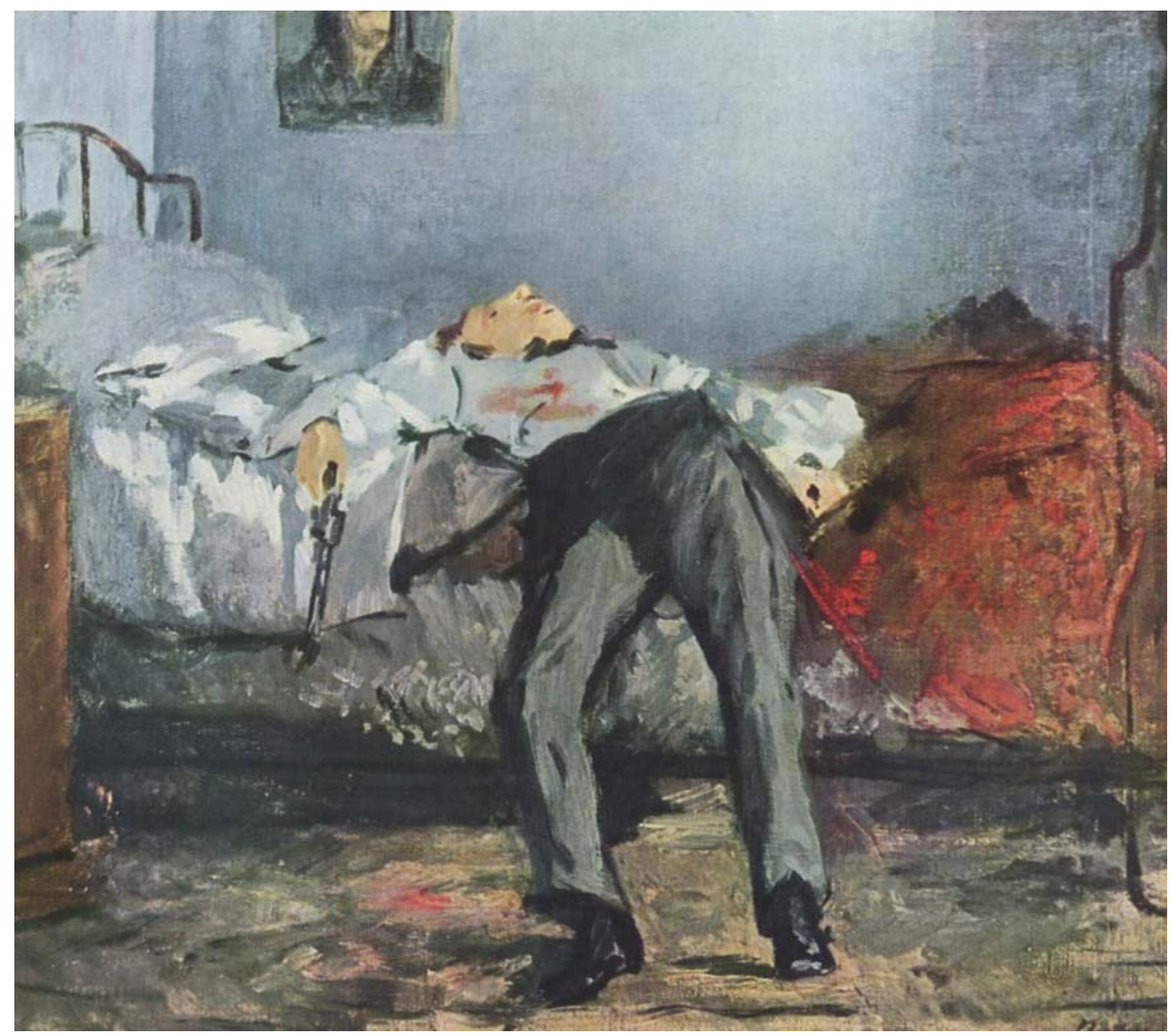

O quadro de Renoir provoca-nos a sensação de um corpo estendido, ainda flácido sobre a cama. Sua postura é largada, assimétrica, em que seu enquadra-

8 Disponível em: http://obviousmag.org/do_ser/2016/o-poder-da-arte-conheca-o-impressionista-francesmanet.html. Acesso em: 17 fev. 2020. 
mento em relação à cama e ao quarto provoca-nos a reflexão de que existe um diálogo entre a obra e o criador - na angústia da vida vivida fora da arte e na arte, isto é, aquele fazer cotidiano tantas vezes desesperador; explicação/complementação - situações amiúde vivenciadas por Lúcio - e a representação de Renoir - artista que transpôs a bruma. Lugar acinzentado, em desordem, no entanto, plenamente harmônico com o tempo da morte.

No desenvolvimento dos pressupostos teóricos bakhtinianos, o teórico observa que existem entre os dois mundos (vida e arte) situações diferentes, análogas ou uma interconexão que os leva fatalmente à interdependência.

$\mathrm{Na}$ criação do quadro impressionista do suicídio apresentado, associam-se as cores do lugar e do tempo que parecem ser um "depois", como a volta do trabalho, a saída de um encontro infeliz ou de qualquer situação sem êxito, pois o suicida está completamente vestido conforme os homens da época. A decisão já estava tomada. Daria cabo à vida.

O quadro capta a morte como associada a um ideal, porém vazio de ato heroico. Um ato de um homem que finaliza uma trajetória de insatisfação, momento em que só a arte poderia trazer uma efêmera sensação de alívio em direção à bruma, ao desconhecido. Nesse momento, tudo é paralisado: local, tempo (passado e presente) e, a partir do portal, o esfumaçamento do verossímil e do inverossímil até o devir.

No livro que estamos estudando, todas as impressões de Lúcio em relação às pessoas começam sempre pelo corpo. Detalhes corporais sucessiva e perfeitamente adjetivados por cores em seus valores simbólicos, decorrentes das experiências e do contexto cultural, com ênfase para o dourado.

No capítulo 1, poderemos destacar as expressões: "braços serpentes de esmeraldas"; "Das mulheres, duas eram loiras, pequeninas, pele de rosas e leite"; "pele dourada"; "[...] e uns cabelos fantásticos, de um ruivo incendiado [...]"; "Jenny e Dora - sem também despregarem ainda de Gervásio, um só instante, os olhos azuis e louros - percepção de Lúcio"; "Os cabelos da primeira eram pretos, e a sua carne esplêndida de sol"; "As pernas, talhadas em aurora loura"; "cabelos de um louro sujo"; "lábios que, num requinte, ela dourara"; "sexo áureo"; "[...] e as unhas douradas?".

O próprio Lúcio pergunta-se se as unhas douradas seriam reais, uma metonímia que toma a parte pelo todo, uma vez que tudo indicava o áureo, irreal e imaginário do teatro. As cores não eram provenientes da física, mas do encanto do teatro e do valor que os espectadores lhe atribuíam. O Dicionário de símbolos ensina:

Intenso, violento, agudo até à estridência, ou amplo e cegante como um fluxo de metal em fusão, o amarelo (e por conseguinte, o dourado) é a mais quente, a mais expansiva, a mais ardente das cores, dificil de atenuar e que extravasa sempre dos limites em que o artista desejou encerrá-la. Os raios do Sol, atravessando o azul celeste, manifestam o poder das divindades do Além (CHEVALIER; GHEERBRANT, 2007, p. 40).

Isso era tudo que aqueles corpos loiros de unhas e cabelos dourados significavam na autoficção A confissão de Lúcio, de Mário de Sá-Carneiro.

Mas as descrições corporais abordam também o corpo masculino com o mesmo tratamento e tonalidade. Continua a descrição do corpo no registro de Ricardo (no capítulo 2): "[...] em lábios de ouro"; "Se eu fosse mulher, nunca me deixaria 
possuir pela carne dos homens - tristonha, seca, amarela: sem brilho e sem luz [...]". Lúcio agora descreve Marta (capítulo 3): "linda mulher loira,"; "o seu olhar azul [...]"; "Um rosto formosíssimo, de uma beleza vigorosa, talhado em ouro"; "mãos inquietantes de esguias e pálidas". Igualmente, no capítulo 6, Lúcio fala de um companheiro de cela: "muito branco, rosadinho e loiro".

Tanto Marta quanto o companheiro de cela, nas descrições de Lúcio, apresentam as cores dos lugares e dos tempos em que são colocados: Marta, em azul e ouro, direciona a sedução - em si um tempo quimérico - em sua casa/quarto com rituais de sedução, enquanto o companheiro traz o desbotado da falta de sol e vigor. O cabelo não é mais "ouro", mas "loiro", apenas uma marca descritiva paralela ou fora da metáfora que, agora, ganha uma marca mais frágil ou transfigurada.

Ainda conforme o Dicionário de símbolos, seguiremos o caminho do dourado, do loiro e do ouro, tão enaltecidos e reafirmados em A confissão de Lúcio, para entender o espaço da cidade de Paris e o tempo das vivências artísticas e afetivas, da revolução dos costumes e da inovação de todas as artes, inclusive a literária:

Considerado na tradição o mais precioso dos metais, o ouro é o metal perfeito. [...] Tem o caráter ígneo, solar e real, até mesmo divino [...] O fundo dos ícones bizantinos é sempre dourado, reflexo da luz celeste (CHEVALIER; GHEERBRANT, 2007, p. 669).

A Capital das Luzes, a Cidade Luz, passa a ser cenário de fundo da imaginação, o espaço e tempo da obra de arte. O lugar é o ponto de partida da imaginação. O concreto externo que penetra no criador e provoca sensações que humanizam e corporificam a cena (espaços e ações) na história. "Sombra, evocando mordoradamente perfumes esfingicos, luas amarelas, crepúsculos de rouxidão. Beleza, perversidade, vício e doença [...]"; "Paris, estabelecimento, na Porta Maillot, tomamos o tramway para Montparnasse" (capítulo 1). Aquilo que é moderado com o complemento de "luas amarelas", "crepúsculos de rouxidão". Tempo e lugar fixam-se no texto e no leitor. O tempo e o espaço se encavalam, entrecruzam-se e produzem o mais eficiente cronotopo: com o passar do tempo, alguns meses (anos para alguns) que aqueles artistas moraram em Paris.

Já o espaço da cidade aqui estudado é liberado de suas angústias, amores desfeitos, espetáculos, festas e equívocos persistentes sob a escritura da autoficção de Mário de Sá-Carneiro. É a Literatura redimindo a condição humana em todos os quadrantes do mundo (espaços) e em diversas épocas (tempos). Paris-Lisboa - final do século XIX - Primeira Guerra Mundial - Literatura de autoficção - leitores do século XXI: tempo e espaço revogados, mas intrínseca e concomitantemente imbricados. Trata-se do cronotopo bakhitiniano perfeito. Teoria da Literatura aliada à melhor Prática Literária.

\section{Conclusões}

Ao final desta autoficção, na qual procuramos localizar o cronotopo bakhtiniano na obra A confissão de Lúcio, de Mário de Sá-Carneiro, e dentro disso focalizar a metáfora da bruma como concretização da comunhão tempo-espaço, chegamos às considerações finais, em que esperamos poder fazer um apanhado 
sobre este estudo de Bakhtin que flui a partir das sensações emanadas de Paris, a Cidade Luz que incitou muitos artistas e, principalmente, os personagens desta autoficção a pensarem as artes sempre em interconexão entre si e sob os ditames espaçotemporais.

Indagar sobre como um artista produz o belo é, desde os clássicos gregos, uma inquietação de muitas interpretações, sejam elas a partir da cultura, da visão ampliada do outro, enfim, dos diálogos construídos entre os seres humanos que elaboram suas concepções em diferentes áreas e/ou expressões.

A ação dialógica da linguagem, base dos estudos bakhtinianos, pareceu-nos um recurso importante para a discussão sobre a autoficção e o quanto as outras artes foram importantes para a realização da criação verbal assumida por Mário de Sá-Carneiro e, nela, a demonstração do cronotopo. Porém, com engenho, $A$ confissão de Lúcio apresenta a possibilidade de haver um tempo e um lugar a partir da sensação, o que chamamos de "metáfora da bruma".

No decorrer da narrativa, como em um carrossel, passam em relevo a música, o teatro, a pintura e a arquitetura. Neste livro, a literatura e as outras artes expõem o sensacionismo. Cada uma delas com seu foco: na música, os compassos que usaram o cronotopo para atingir todos os sentidos; na arquitetura, a vertigem provocada pelos arcos, cores, formas e dimensões; no teatro, a capacidade de construir o verossimil ou inverossimil, a ponto de criar uma só bailarina como um ser coletivo. Ainda, nele, a presença do personagem-coisa, a iluminação como se estivesse em relação com uma câmera cinematográfica, sugerindo para o olhar do espectador a sensação desejada pela diretora - a americana; na pintura, a expressão quase audível do diálogo entre criador e criatura; a arte cromática como se fosse um foco provocador e indicial para situar um colóquio entre homem/tempo/espaço a partir do corpo.

Acreditamos que o aproveitamento da percepção de Bakhtin sobre a natureza dialógica da linguagem e a observação de categorias filosófico-fundamentais de sua obra, sem a intenção de realizar análise classificatória (dialogia, polifonia, alteridade, entre outros), ensejou e construiu a base para que pensássemos outras formas de organizações discursivas.

Quanto à autoficção em si, embora a narrativa dê a sensação de que lemos um romance como outros, em que o tempo pode ser cronológico ou psicológico, o autor cria o ardil do cronotopo imagético - a metáfora da bruma -, que prepara a finalização aberta do texto.

Quanto à problematização levantada no início do trabalho sobre qual seria o comprometimento das artes na representação do tempo e espaço na autoficção de Mário de Sá-Carneiro, acreditamos que o próprio autor desenvolve a narrativa com os diálogos que os artistas costumavam travar em sua convivência na vida boêmia de Paris, na Belle Époque. Por isso, a Paris daquele tempo pode ser comparada a um carrossel, porque a cada esquina apresentava motivos para que o belo fosse apreciado na perspectiva de um observador diante dele. Isso ocorre para que tanto os personagens quanto os leitores possam vivenciar ainda outro cronotopo - inverossimil e evidente.

A partir do livro, ficção, realidade e imaginário, novas visões estéticas vêm sendo experimentadas, instigando a discussão que o autor entrevê em sua biografia ou autobiografia. A inteligência e a sensibilidade humana são cobertas por uma "bruma" que ajuda a delinear a fronteira entre ciência e imaginação, objetividade e evasão, verossimil e inverossimil. 
Não há necessidade de se invocar toda a argumentação disponivel para classificar esta obra de Mário de Sá-Carneiro como uma autoficção. Bastaria apresentar a opinião dos editores da obra Loucura... e $O$ incesto manifestada na "Nota Editorial" firmada por eles no início da sua publicação no Brasil, que passamos a transcrever:

Em Loucura e O Incesto, duas novelas fascinantes de seu primeiro livro, encontramos já todo o Sá-Carneiro das obras posteriores, o Sá-Carneiro de sempre, talvez o caso de maior coerência entre a obra e a vida-em óbvio prejuizo da última - que se conheça nas letras portuguesas, [...] Mário de Sá-Carneiro, o absoluto esteta e o suicida, é, na língua portuguesa, uma trágica resistência ao afastamento entre literatura e vida, coisas, coisas que sempre concebeu unidas e unidas cumpriu radicalmente (SÁ-CARNEIRO, 1997, p. 6).

O homem é um caçador de sentidos. Esta autoficção constitui uma exemplar manifestação literária que busca justamente encontrar um sentido para as relações entre a Vida e a Arte, num passado perfeito e num presente perpétuo, tanto aqui quanto nalguma ou em nenhuma parte.

\section{Time And space in the self-Fiction The confession of LÚCio, by MáRIo de SÁ-CARNEIRO}

Abstract: Self-fiction The confession of Lúcio, by Mário de Sá-Carneiro, is a narrative in which the character Lúcio, a Portuguese writer, confesses, after ten years in prison, that he had not committed the crime for which he was paying. Faced with the question of what would be the commitment of the arts in the representation of time and space in the self-fiction of Mário de Sá-Carneiro, this article aims to associate the Bakhtinian chronotope with the mist metaphor, a symbolic form we created to analyze how the writer modernist and sensationalist built sensations, reflections of the characters, and actions from the images provided by the Parisian arts, combining time and space with daydreaming imagery. The methodological reflection will be restricted to the analysis of the moments/dialogues in which the artists talk about themselves, the sensations, and the arts.

Keywords: Self-fiction. Chronotope. Literature and other arts. Imagery metaphors. Time and space.

\section{REFERÊNCIAS}

AMORIM, M. Cronotopoe exotopia. In: BRAIT, B. (org.). Bakhtin: outros conceitos-chave. 2. ed. São Paulo: Contexto, 2012. p. 95-114.

BAKHTIN, M. Estética da criação verbal. Tradução Maria Ermantina Galvão Gomes Pereira. São Paulo: Martins Fontes, 2010.

BAKHTIN, M. Problemas da poética de Dostoieuski. 2. ed. Tradução Paulo Bezerra. Rio de Janeiro: Forense Universitária, 1997.

BAKHTIN, M. Questões de literatura e de estética: a teoria do romance. Tradução Aurora Fornoni Bernardini et al. 7. ed. São Paulo: Hucitec, 2014. 
BORGES FILHO, O.; BARBOSA, S. A Istambul de Orhan Pamuk: cronotopo, esquartejamento, memória e identidade. Cerrados 40 - Revista do Programa de Pós-Graduação em Literatura, ano 24, n. 40, p. 315-337, 2015.

BOURDIEU, P. A distinção: crítica social do julgamento. Tradução Daniela Kern e Guilherme F. Teixeira. São Paulo: Edusp, 2015.

CHEVAliER, J.; GHEERBRANT, A. Dicionário de símbolos. 21. ed. Tradução Vera da Costa e Silva et al. Rio de Janeiro: José Olympio, 2007.

COSTA, P. C. L. As dimensões artísticas e literárias do Projecto Sensacionista. 1990. Dissertação (Mestrado em Literaturas Comparadas Portuguesa e Francesa) - Faculdade de Ciências Sociais e Humanas da Universidade Nova de Lisboa, Lisboa, 1990.

COUTINHO, A. Crítica literária. In: COUTINHO, A. Notas de teoria literária. 2. ed. Rio de Janeiro: Civilização Brasileira, 1978.

DICIONÁRIO Online de Português. Disponivel em: https://www.dicio.com.br/ aurelio-2/. Acesso em: 27 jul. 2020.

DOUBROVSKY, S. Fils. Paris: Éditions Galilée, 1977.

FAEDRICH, A. Autoficção: um percurso teórico. Criação \& Crítica, São Paulo, n. 17, p. 30-46, dez. 2016.

LEJEUNE, P. O pacto autobiográfico: de Rousseau à internet. Tradução Jovita Maria Gerheim Noronha e Maria Inês Guedes. Belo Horizonte: Ed. UFMG, 2014. LINS, O. Lima Barreto e o espaço romanesco. São Paulo: Ática, 1976. (Ensaios). MACHADO, I. A. de. Gêneros discursivos. In: BRAIT, B. (org.). Bakhtin: conceitos-chave. 5. ed. São Paulo: Contexto, 2012. p. 151-166.

SÁ-CARNEIRO, M. A confissão de Lúcio. 4. ed. Lisboa: Ática, 1973.

SÁ-CARNEIRO, M. Loucura...e O Incesto. Rio de Janeiro: Lacerda, 1997.

TUAN, Y. Topofilia: um estudo da percepção, atitudes e valores do meio ambiente. Tradução Livia de Oliveira. São Paulo: Difel, 1980. 